\title{
Tools used to estimate soil quality in coal combustion waste areas
}

\author{
FLAVIO M.R. DA SILVA JÚNIOR ${ }^{1}$ and VERA M.F. VARGAS ${ }^{2}$ \\ ${ }^{1}$ Laboratório de Ensaios Farmacológicos e Toxicológicos/ LEFT, Instituto de Ciências Biológicas, \\ Universidade Federal do Rio Grande/ FURG, Av. Itália, Km 8, Campus Carreiros, 96203-900 Rio Grande, RS, Brasil \\ ${ }^{2}$ Programa de Pesquisas Ambientais, Fundação Estadual de Proteção Ambiental Henrique L. Roessler (FEPAM), \\ Avenida Salvador França, 1707, 90690-000 Porto Alegre, RS, Brasil
}

Manuscript received on February 4, 2013; accepted for publication on September 9, 2013

\begin{abstract}
Soil is a highly complex environmental compartment that has suffered with the contamination of substances of various origins. Among the main activities that affect soil quality are power generation activities that use fossil fuels, such as mineral coal. Environmental protection agencies encourage scientific investigations using tools described in legal devices or standard protocols to evaluate the potential of coal as a pollutant, especially in places that have large reserves of this mineral like the state of Rio Grande do Sul. The aim of this study was to characterize the leached extracts of different soils from an area influenced by coal waste, to classify them according to the guideline values for groundwater described in CONAMA's n. $420 / 2009$, and to estimate the effects of the leachates ingestion in DNA mutation rates. The volume of soil needed to induce a $100 \%$ increase in the spontaneous mutation rate varied between 129.3 and $1544.1 \mathrm{mg}$ of soil among the soils studied. Metals such as $\mathrm{Mn}, \mathrm{Pb}, \mathrm{Cd}$ and $\mathrm{Ni}$ surpassed the investigation limits for groundwater at least in one soil sample. The results showed that there can be transfer of soil contaminants to groundwater and soil intake in the area could contribute to the increased mutagenic risk.
\end{abstract}

Key words: groundwater, mutagenesis, soil ingestion, risk assessment.

\section{INTRODUCTION}

Population growth, rapid industrial development and the intensive use of natural resources by agriculture, livestock and mining have contributed to the unrestrained discharge of solid and liquid wastes, which have greatly increased the number of contaminated areas, thus worsening environmental problems (Gilmore 2001, Atlas and Bartha 2002). According to Gilmore (2001), soil contamination is the greatest obstacle of sustainable development, since this problem drastically affects the "health" of the ecosystem and acts directly on the loss of biological diversity.

Correspondence to: Flavio Manoel Rodrigues da Silva Júnior E-mail: f.m.r.silvajunior@gmail.com
From an environmental standpoint, soils are closely related to the other compartments. They behave as a source and as storage for air and water contaminants. In human beings contaminants from soil can harm health and the ingestion of these elements is a major form of exposure (Calabrese et al. 1997).

Conservative estimates adopt a value of around $100 \mathrm{mg}$ for the daily ingestion of soil by a young child (Stanek et al. 1997), while studies report events of geophagy where up to $60 \mathrm{~g}$ of soil were being consumed by a child (Calabrese et al. 1997). The United States Environmental Protection Agency (USEPA 1996, 2002) considers that the daily rate of 
soil ingestion by children, adults and in geophagy events is up to $200 \mathrm{mg}, 50 \mathrm{mg}$ and $10 \mathrm{~g}$, respectively. Recently, these values were recalculated considering the daily rate of soil ingestion by children, adults and in geophagy events to up to $30-200 \mathrm{mg}, 20 \mathrm{mg}$ and $50 \mathrm{~g}$, respectively (USEPA 2011).

In Brazil, the number of studies involving problems related to soil pollution has grown (Da Silva Júnior and Vargas 2009, Da Silva Júnior et al. 2009, 2013), and there has been greater interest in investigating the impact of environmental contamination on soil quality after CONAMA's (Conselho Nacional do Meio Ambiente) Resolution 420/2009 was published. This was the first legal provision, on a national level which dealt with criteria and guiding values for soil quality (CONAMA 2009). Besides the guiding values for soil quality, the Resolution deals with groundwater values, because of the close relationship between this compartment and the soil.

In the state of Rio Grande do Sul, environmental contamination by coal wastes is one of the fields of interest of the state environmental agency, Fundação Estadual de Proteção Ambiental (FEPAM). The state has about $90 \%$ of the more than 30 million tons of coal reserves in Brazil (Neves and Chaves 2000), and this plays an important role in job and income generation for the inhabitants of many towns in the state.

Brazil has large mineral coal reserves and uses this matrix to produce energy, especially in the south region, even though it is known that coal rejects harm human health and the environment, whether they are from mining or from burning in thermal power plants (Celik et al. 2007).

In this study, the leachates of different soils from an area under the influence of coal waste were classified according to the guide values for groundwater (CONAMA Resolution 420/2009). Mutagenic risk in populations that ingested the leachates was also estimated. In order to achieve the latter objective, we used the mutagenic potential values and the spontaneous mutation rates obtained in a prior study (Da Silva Júnior and Vargas 2009) which evaluated the mutagenicity of samples from these soils using the Salmonella/microsome assay to calculate the volume of soil needed to induce a $100 \%$ increase in the spontaneous mutation rate.

\section{MATERIALS AND METHODS}

AREA OF STUDY AND SAMPLING

The study was performed in the area under the influence of a coal-fired power plant located in the Carboniferous Microregion of the Lower Jacuí. Sites were defined within the area of study selected for this work to evaluate the potential residual impacts on soil generated by burning mineral coal and disposal of its ashes in a low energy potential thermal power unit. The area where the plant is located is moderately distant from large urban centers (approximately $70 \mathrm{~km}$ from Porto Alegre), on the banks of a major river of the region (Jacuí River) which, downstream from the plant, flows together with other state rivers (Gravataí, Sinos and Caí) forming the Jacuí Delta, and then the Guaiba Lake. In this way, contaminants potentially leached from the soil in this area and entrained to the river, can be added to the pollutants from other areas, causing indirect damage to the population of these regions.

Extensive monitoring was performed throughout the area of influence of the thermal power plant. This included terrestrial and aquatic organisms, toxicity tests, besides groundwater quality parameters, investigation of surface waters and, in the Jacuí River sediments, within the area of influence of this plant (FEPAM 2005).

Thus, soil samples were collected at strategic sites to predict the dispersion of contaminants to adjacent areas that were still relevant to estimate harm to human health and the environment. The central point sampled was a heavy ash deposit in the process of recovery. The site was the target of 
ashes newly burned at the coal-fired power plant for a few decades, but because of the environmental agency requirements it is now undergoing a process of environmental recovery. Besides the soil samplings from this deposit, samples were also removed from the areas below (riparian forest of Jacuí river and grazed wet field) and above the level of the deposit (child recreation area). Additionally, the control soil was collected in a region near the coal-fired power plant, although without the direct influence of deposit leaching or chimney smoke. Sampling details are described in Da Silva Júnior and Vargas (2009).

\section{OBTAINING SOIL EXTRACTS}

Soil samples were shaken $(115 \mathrm{rpm})$ at $20^{\circ} \mathrm{C}$ for $24 \mathrm{~h}$ with a $5.7 \mathrm{~mL}$ solution of acetic acid P.A. and sodium hydroxide $1 \mathrm{M}$ prepared in $1000 \mathrm{~mL}$ of deionized water ( $\mathrm{pH} 4.93 \pm 0.05$ - soil: solvent, $1: 2, \mathrm{~g} / \mathrm{mL}$; leached extract) and then centrifuged at $13,000 \mathrm{x}$ g for 15 minutes at $4^{\circ} \mathrm{C}$, filtered $(0.45 \mu \mathrm{m}$ Millipore), divided into aliquots and stored at $4^{\circ} \mathrm{C}$ for at least 24 hours, for mutagenic evaluation or chemical analysis of the metals.

\section{OBTAINING MutagenIC DATA}

Data on the mutagenic potential and spontaneous mutation values (negative control) were taken from Da Silva Júnior and Vargas (2009). In this study, the soil mutagenicity was evaluated in five sampling areas: coal ash deposit in a recovery process; an area of riparian forest at Jacuí river (riparian forest), an old agricultural area (field area) and a recreation area for children (recreation area). In addition, the control area is located in a contaminant-free riparian forest.

Mutagenicity data from three strains in leached extracts were used in the presence and absence of S9 mix: TA98 (the target of the mutation was the $-\mathrm{C}-\mathrm{G}-\mathrm{C}-\mathrm{G}-\mathrm{C}-\mathrm{G}-\mathrm{C}-\mathrm{G}-\mathrm{sequence}$ in the gene that encodes histinidol dehydrogenase), TA97a (the target of the mutation was the $-\mathrm{C}-\mathrm{C}-\mathrm{C}-\mathrm{C}$ -
$\mathrm{C}-\mathrm{C}$ - sequence in the gene that encodes histidinol dehydrogenase) and TA100 (the target of the mutation was the reversion of the proline amino acid -GGG- sequence by a leucine-GAG- in the gene of N'-5'-phosphoribosyl-ATP transferase) (Da Silva Júnior and Vargas 2012).

\section{CALCULATION OF THE VOLUME OF SOIL FOR THE INDUCTION} OF Mutagenic Potential (V100\%)

In order to calculate the volume of soil needed to induce the mutagenic potential, the mutagenic potential obtained from the dose-response curve for each strain in the different soil samples and the spontaneous mutation value (in revertants) for each strain were taken into account, in the presence or absence of the liver metabolization fraction, following the formula:

$$
V 100 \%=(\mathrm{ME} \times 2) / \mathrm{MP}
$$

where $V 100 \%$ is the volume of soil needed to induce a $100 \%$ increase in the spontaneous mutation rate; $\mathrm{ME}$ is the spontaneous mutation value in revertant colonies and MP is the mutagenic potential. The data were compared to the levels of daily soil ingestion in children, according to USEPA (2002) (200 mg/day), in procedures similar to Pohren et al. (2012).

\section{OBTAINING CHEMICAL DATA}

Metals (Mn, Fe, Al, Zn, Cu, Cd, Pb, Cr e Ni) in the leached extracts were quantified by inductively coupled plasma - optical emission spectrometry (ICP-OES) with the following limits of detection in $\mathrm{mg} / \mathrm{L}: \mathrm{Cu}-0.004 ; \mathrm{Zn}-0.02 ; \mathrm{Fe}-0.04 ; \mathrm{Mn}-0.03$; Al-0.08; Cd-0.002; Cr-0.004; Ni-0.002; Pb-0.01. They were determined at the Soil Laboratory of the Federal University of Rio Grande do Sul (UFRGS), according to the methodology recommended by USEPA (2007).

The values were transformed into $\mu \mathrm{g} / \mathrm{L}$ and compared to the guiding values of investigation for groundwater established in CONAMA's 
Resolution 420/2009 (CONAMA 2009), due to the leaching of soil being an important escape route of contaminants to the aquatic compartment (Da Silva Júnior and Vargas 2009).

\section{RESULTS}

SOIL VOLUME FOR THE INDUCTION OF THE MUTAGENIC

Potential $(V 100 \%)$

Regarding the mutagenicity results, $V 100 \%$ varied from 129.3 to $1544.1 \mathrm{mg}$ of soil. A value of less than $200 \mathrm{mg}$ per day (average daily levels of soil ingestion per children according to the USEPA 2002) was estimated only in a single episode when the leachate of soil from the riparian forest area was tested. The other areas (ash deposit, field area and recreation area) did not have $V 100 \%$ lower than $200 \mathrm{mg}$, but in the more critical scenarios the values were close to the limit values (Table I).
TABLE I

Soil volume necessary for the induction of mutagenic potential (V100\%)

\begin{tabular}{lcccccc}
\hline & \multicolumn{3}{c}{ Without S9 } & \multicolumn{3}{c}{ With S9 } \\
\cline { 2 - 7 } & TA98 & TA97a & TA100 & TA98 & TA97a & TA100 \\
\hline $\begin{array}{l}\text { Control } \\
\text { soil }\end{array}$ & - & - & - & - & - & - \\
$\begin{array}{l}\text { Deposit } \\
\text { Riparian }\end{array}$ & - & - & - & 380.7 & 699.4 & - \\
$\begin{array}{l}\text { Forest } \\
\text { Field area }\end{array}$ & - & - & - & 600.2 & - & - \\
$\begin{array}{l}\text { Recreation } \\
\text { area }\end{array}$ & - & - & 286.9 & 356.3 & - & 432.3 \\
\hline
\end{tabular}

The $200 \mathrm{mg}$ threshold of soil ingestion can be reached in $0.6 ; 1.4 ; 1.9$ and 3 days, respectively, in the riparian forest area, recreation area, ash deposit and field area. The soil of the control area did not induce mutagenicity and, therefore, $V 100 \%$ could not be calculated (Table I).

TABLE II

Comparison of chemical data obtained from soil samples with the values of Resolution 420/2009

\begin{tabular}{ccccccc}
\hline & Control soil $^{\mathbf{1}}$ & Deposit $^{\mathbf{1}}$ & Riparian forest $^{\mathbf{1}}$ & Field area $^{\mathbf{1}}$ & Recreation area $^{\mathbf{1}}$ & Guideline values $^{\mathbf{2}}$ \\
\hline $\mathbf{Z n}$ & 320 & 90 & 230 & 160 & 300 & 1050 \\
$\mathbf{F e}$ & ND & 110 & 220 & ND & 710 & 2450 \\
$\mathbf{M n}$ & $\mathbf{1 1 2 0 0}$ & 100 & 390 & $\mathbf{1 1 0 0}$ & 140 & 400 \\
$\mathbf{A l}$ & 680 & 1340 & 2530 & 960 & 3120 & 3500 \\
$\mathbf{C r}$ & 10 & 5 & 10 & ND & 10 & 50 \\
$\mathbf{C u}$ & 69 & 32 & 59 & 40 & 38 & 2000 \\
$\mathbf{P b}$ & $\mathrm{ND}$ & ND & 10 & 10 & $\mathbf{2 0}$ & 10 \\
$\mathbf{C d}$ & 4 & 7 & $\mathbf{1 8}$ & 3 & 7 & 5 \\
$\mathbf{N i}$ & $\mathbf{2 9}$ & 6 & $\mathbf{2 8}$ & 7 & 19 & 20 \\
\hline
\end{tabular}

${ }^{1}$ Amounts calculated based on the results obtained by Da Silva Júnior and Vargas (2009).

${ }^{2}$ CONAMA (2009).

COMPARISON OF CHEMICAL DATA WITH THE VALUES OF

RESOLUTION 420/2009

All leached soil extracts investigated surpassed the groundwater investigation values for at least one of the elements analyzed. The extract of soil from the control area presented manganese and nickel values that surpassed the legal limits. The extract of the soil from the ash deposit area had cadmium levels above legal level, while cadmium and nickel surpassed the investigation limits in the extract of riparian forest soil. The field area showed manganese levels above the limits of investigation, while in the recreation area the levels of lead and cadmium were above the legally established limits (Table II).

\section{DISCUSSION}

In the evaluation/diagnosis studies on contaminated soils, many tools are used to measure alterations 
of the ecosystem, and these are called soil quality indicators. Lanna (2002) divides these indicators into two distinct groups: inherent (physical and chemical parameters) and dynamic (biological parameters). With regards to the use of tools to evaluate environmental and health risks, the association between chemical and biological parameters appears to be an important strategy to predict environmental damage. In the state of Rio Grande do Sul, areas that are under the influence of mineral coal extraction or industrial utilization have received special attention from the environmental agencies, because of the large reserves in the state.

The use of fossil mineral coal as a source of energy in Brazil on a large scale, together with the high potential for pollution of this energy matrix, highlights the importance of studies to diagnose, monitor and enforce its appropriate use, besides the final disposal of its wastes by environmental control agencies. Once they have been deposited in the soil, the coal wastes can cause harm to fauna and flora for example or cause damage at subcellular levels (Da Silva Júnior et al. 2009, Podgaiski et al. 2001, Podgaiski and Rodrigues 2010).

Organic and inorganic extracts of soil sampled in the study area have already shown mutagenic induction using different strains in the presence or absence of metabolization (Da Silva Júnior and Vargas 2009) and these authors identified three important pathways for mutagenic contaminant dispersion in the areas: surface runoff, soil leaching and atmospheric dispersion. The first two routes cited have a marked influence on the transfer of contaminant into the aquatic compartment, especially into groundwater, when the soil has little or no efficacy in retaining contaminants.

In fact, the relationship between soil and groundwater is covered in CONAMA's Resolution $420 / 2009$, and in this study we attempted to simulate a soil leaching condition to predict the transfer of contaminants from the soil to the aquatic compartment. The leached extracts of all soil samples investigated showed values above the limits of the Resolution for at least one metal (as in the case of the ash deposit and field area).

Taking into account that the riparian forest is located immediately below the area of the coal ash deposit, the importance of leaching and of surface runoff of contaminants in the studied region becomes clear, since the concentration of all metals in the leached extract of riparian forest was higher when compared to the leached extract of the deposit, including levels of cadmium and nickel above the legal limits. This ability of toxic metals to migrate from soil to groundwater have already been demonstrated, even in areas with past outbreaks of pollution (McBride et al. 1997, Rattan et al. 2005). Moreover, some metals present in soil samples and other complex mixtures have shown mutagenicity measured by Salmonella/microsome assay (Nestmann et al. 1979, Mandel and Roser 1984, Pohren et al. 2012).

In addition to the transfer of contaminants between environmental compartments, a major form of exposure to contaminants present in the soil can also be through voluntary or involuntary ingestion (Calabrese et al. 1997) and, in all of the scenarios, this form of exposure is prevalent in children. USEPA points out that $95 \%$ of children ingest $200 \mathrm{mg}$ /day of soil. Pohren et al. (2012) used the value as a reference to estimate the mutagenic risk of exposure to soils at contaminated sites. In our study, except for the soil from the area of reference, the other soil samples presented the lowest $V 100 \%$ varying from 129.3-600.2 $\mathrm{mg}$ of soil. In decreasing order of potential mutagenic risk we can list: riparian forest $>$ recreation area $>$ ash deposit $>$ field area, corroborating with the hypothesis that the riparian forest receives powerful contributions of leaching of ash deposit.

In the least severe scenario (exposure to soil in the field area), three days would be enough time to reach $V 100 \%$, which is the volume needed to induce a $100 \%$ increase in mutation rates. If we 
consider the possibilities of chronic exposure to these soils, or even exposure in geophagy events (voluntary ingestion of soil), this picture becomes more critical, potentiating the risk of exposure to the analyzed soils. Finally, although it does not have the lowest $V 100 \%$ values among the soils investigated, special attention must be given to the soil in the recreation area, since it is characterized as the region with the greatest possibility of exposure, especially for children.

The tools used to evaluate soil quality allowed for indicating the contribution of soils contaminated by coal wastes to groundwater contamination by simulating a leached extract and, based on guiding values of CONAMA's Resolution 420/2009, estimate the mutagenic risk of exposure to these soils considering the scenario presented by USEPA of $200 \mathrm{mg} /$ day of soil ingested by children.

\section{RESUMO}

O solo é um compartimento ambiental altamente complexo e tem sofrido com a contaminação de substâncias de origens diversas. Entre as principais atividades que contribuem para a perturbação da qualidade dos solos estão as atividades de geração de energia pela queima de combustíveis fósseis, como o carvão mineral. As agências de proteção ambiental têm encorajado investigações científicas usando ferramentas presentes em dispositivos legais ou protocolos padronizados para avaliar o potencial poluidor do carvão mineral, especialmente em locais com grandes reservas, como o estado do Rio Grande do Sul. Este estudo teve por objetivo enquadrar os extratos lixiviados de diferentes solos de uma área influenciada por resíduos de carvão nos valores orientadores para água subterrânea da CONAMA 420/2009 e estimar a contribuição que a ingestão destes solos pode oferecer no incremento das taxas de mutação de DNA. O volume de solo necessário para induzir um aumento de $100 \%$ na taxa de mutação espontânea variou entre 129,3 e 1.544,1 mg de solo entre os solos estudados. Metais tais como $\mathrm{Mn}, \mathrm{Pb}, \mathrm{Cd}$ e Ni ultrapassaram os limites de investigação para as águas subterrâneas, pelo menos, em uma amostra de solo. Os resultados obtidos mostraram que é possível haver transferência de contaminantes do solo para a água subterrânea e que a ingestão de solo na área pode contribuir para o aumento do risco mutagênico.

Palavras-chave: água subterrânea, mutagênese, ingestão de solo, medição de risco.

\section{REFERENCES}

ATLAS RM AND BARTHA R. 2002. Ecología microbiana y Microbiología Ambiental. Madrid: Pearson Educación.

Calabrese EJ, StaneK EJ, James RC And Roberts SM. 1997. Soil Ingestion: a concern for acute toxicity in children. Environ Health Perspect 105:1354-1358.

Celik M, Donbak L, Unal F, YÜZBasioglu D, AKsoy H and YILMAZ S. 2007. Cytogenetic damage in workers from a coal-fired power plant. Mutat Res 627:158-163.

CONAMA - Conselho Nacional do MeIo Ambiente. 2009 Resolução no 420, de 28 de dezembro de 2009. "Dispõe sobre critérios e valores orientadores de qualidade do solo quanto à presença de substâncias químicas e estabelece diretrizes para o gerenciamento ambiental de áreas contaminadas por essas substâncias em decorrência de atividades antrópicas.", Diário Oficial [da República Federativa do Brasil], Brasília, DF, nº 249, de 30/12/2009, p. 81-84.

DA SILVA JÚNIOR FMR, ROCHA JAV AND VARGAS VMF. 2009 Extraction parameters in the mutagenicity assay of soil samples. Sci Total Environ 427: 6017-6023.

Da Silva Júnior FMR, Silva PF, Garcia EM, Klein RD, Peraza G, BAisch P, VARGas VMF AND MucCILlOBAISCH AL. 2013. Toxic effects of the ingestion of watersoluble elements found in soil under the atmospheric influence of an industrial complex. Environ Geochem Health 35: 317-331.

DA SILVA JÚNIOR FMR AND VARGAS VMF. 2009. Using the Salmonella assay to delineate the dispersion routes of mutagenic compounds from coal wastes in contaminated soil. Mutat Res 673: 116-123.

DA SiLVA JÚNIOR FMR AND VARgas VMF. 2012. Happy Birthday: Forty Years of Salmonella/Microsome Assay. In: MONTE AS and DE SANTOS PE. Salmonella: Classification, Genetics and Disease Outbreaks. New York: Nova Science Publishers, p. 251-260.

FEPAM - FundaÇÃo Estadual de ProteÇÃo Ambiental. 2005. Processo de Licenciamento Ambiental, $n^{\circ}$ 77830567/04-4. Monitoramento ambiental de água superficial, subterrânea, sedimentos, organismos aquáticos, organismos terrestres e plantas terrestres na Região de São Jerônimo/RS no âmbito da área de influência da divisão de produção de São Jerônimo- DTPJ. Relatório Final: Usina Termelétrica São Jerônimo, Município de São Jerônimo/RS, Monitoramento Ambiental, Agosto de 2005. 
GILMORE E. 2001. A Critique of Soil Contamination and Remediation: The Dimensions of the Problem and the Implications for Sustainable Development. Bull Sci Technol Soc 21: 394-400.

LANNA AC. 2002. Impacto Ambiental de Tecnologias, Indicadores de Sustentabilidade e Metodologias de Aferição: Uma Revisão. Santo Antônio de Goiás: Embrapa Arroz e Feijão, 31 p.

MANDEL R AND Roser HJP. 1984. Mutagenicity of cadmium in Salmonella typhimurium and its synergism with two nitrosamines. Mutat Res 138: 9-16.

MCBRIDE MB, Richards BK, STEENHUIS T, RUSSO JJ AND SAUVÉ S. 1997. Mobility and Solubility of Toxic Metals and Nutrients in Soil Fifteen Years After Sludge Application. Soil Sci 162: 48-500.

Nestmann ER, Matula TI, Douglas GR, Bora KC AND KOWBEL DJ. 1979. Detection of the mutagenic activity of lead chromate using a battery of microbial tests, Mutat Res 66: 357-365.

NEVES GR AND CHAVES SHA. 2000. A região carbonífera "tradicional" do Rio Grande do Sul. p.108-129. In: UFRGS. Carvão e Meio Ambiente. Porto Alegre, Editora da Universidade, $1006 \mathrm{p}$.

Podgaiski LR, QuAdros A, ARAuJo P AND Rodrigues GG. 2001. Neotropical woodlice (Isopoda) colonizing leaf-litter of pioneer plants in a coal residues disposal environment. Rev Bras Ciênc Solo (Online) 35: 743-750.

PODGAISKI LR AND RODRIGUES GG. 2010. Leaf-litter decomposition of pioneer plants and detritivore macrofaunal assemblages on coal ash disposals in southern Brazil. Eur J Soil Biol 46: 394-400.
POHREN RS, Rocha JAV, LEAL KA AND VARGAS VMF. 2012. Soil mutagenicity as a strategy to evaluate environmental and health risks in a contaminated area. Environ Int 44: 40-52.

RATTANA RK, DATTA SP, ChHONKAR PK, SURIBABU K AND SINGH AK. 2005. Long-term impact of irrigation with sewage effluents on heavy metal content in soils, crops and groundwater - a case study. Agr Ecosyst Environ 109: 310-322

Stanek EJ, Calabrese EJ, Barnes R And Pekow P. 1997. Soil Ingestion in Adults - Results of a second pilot study. Ecotox Environ Saf 36: 249-257.

USEPA. 1996. Exposure Factors handbook. Washington, DC:U.S. Environmental Protection Agency.

USEPA. 2002. Child-specific exposure factors handbook. National Center for Environmental Assessment, Washington, DC; EPA/600/P-00/002B. Available from: National Information Service, Springfield, VA; PB2003101678 and http://www.epa.gov/ncea

USEPA. 2007. Method 6010C. Inductively Coupled PlasmaAtomic Emission Spectrometry. http://www.epa.gov/sw846/pdfs/6010c.pdf; 2007.

USEPA. 2011. Exposure Factors Handbook: 2011 Edition. National Center for Environmental Assessment, Washington, DC; EPA/600/R-09/052F. Available from the National Technical Information Service, Springfield, VA, and online at http://www.epa.gov/ncea/efh. 